Journal of Advanced Research in Fluid Mechanics and Thermal Sciences

Journal homepage: www.akademiabaru.com/arfmts.html ISSN: 2289-7879

\title{
Variations in The Distance Between Hulls that Affect the Resistance of The Floating Pontoon N219
}

\author{
Yanuar $^{1,}{ }^{*}$, Gunawan $^{1}$, Allessandro Setyo Anggito Utomo $^{1}$, M. F. Tjiptadi ${ }^{1}$, M. N. Luthfi ${ }^{1}$ \\ Department of Mechanical Engineering, Faculty of Engineering, Universitas Indonesia, Indonesia
}

\begin{tabular}{|c|c|}
\hline ARTICLE INFO & ABSTRACT \\
\hline $\begin{array}{l}\text { Article history: } \\
\text { Received } 27 \text { October } 2020 \\
\text { Received in revised form } 12 \text { April } 2021 \\
\text { Accepted } 20 \text { April } 2021 \\
\text { Available online } 16 \text { June } 2021\end{array}$ & $\begin{array}{l}\text { An amphibious plane is an aircraft to carry out cargo delivery and an aircraft for } \\
\text { emergencies to reach remote islands in the archipelago. A pontoon or buoy is a hull } \\
\text { that is useful as a bearing for landings in water areas. This is done to assist aircraft } \\
\text { landing without using an airplane runway. This research aims to create a new } \\
\text { configuration of the distance between one pontoon and another. Numerical } \\
\text { calculations and analysis are useful for seeing the characteristics of the floating } \\
\text { pontoon design's resistance. An investigation of interference waves was also carried } \\
\text { out in this study to validate the experimental data generated by the pontoon hull. } \\
\text { Numerical calculations are carried out on the CFDSOF application to predict hull } \\
\text { resistance with three variations to the floating pontoon's separation distance. The } \\
\text { simulation is carried out at the Operating Empty Weight condition on the Indonesian }\end{array}$ \\
\hline $\begin{array}{l}\text { Keywords: } \\
\text { Plane; Pontoon; Numerical Investigation; } \\
\text { Reduction; Drag }\end{array}$ & $\begin{array}{l}\text { Aerospace aircraft with the IAe N219 model. The results show that the Froude Number } \\
\text { speed is between } 0.3 \text { to } 0.8 \text {. There is a reduction in drag on the hull so which makes } \\
\text { takeoff operations easier. }\end{array}$ \\
\hline
\end{tabular}

\section{Introduction}

Converting conventional type aircraft into amphibious aircraft have been done in many aircraft manufacturers and types such as Cessna 208 Grand Caravan and de Havilland Canada DHC-3 Otters. Meekins and Husa [1] and Liem [2] stated that such aircraft utilize a float shape that stabilize and generates buoyancy to the aircraft on water but does not significantly impede the aircraft's performance in the air. Float designs rely on volume, displacement, and high-speed planning in order achieve minimum speed for aircraft to takeoff. However, seaplane floats designs were already developed since the Second World War and many aspects such as the volume, rake, chine, and step effects has been optimized since then as stated by Tetlow and Smith [3]. Float also features same characteristics as boat hull have, with the only difference is the longitudinal stability according to Canamar Leyva [4]. Most seaplane have twin hull configuration float, which according to Broglia et al., [5] and Ibadurrahman et al., [6] a multihull vessel hull separation and speed impact its resistance. Therefore, the purpose of this research is to analyze the multihull separation configuration at specific

\footnotetext{
* Corresponding author.

E-mail address: yanuar@eng.ui.ac.id

https://doi.org/10.37934/arfmts.83.2.127134
} 
Froude Number range of a twin float pontoon which can be applied to IAe's Nurtanio N219 Aircraft. The water resistance investigation is held to investigate the optimal twin floats configuration designed to get as little water resistance as possible to get a minimum take-off distance on the water. Floats with twin hull is no difference as a catamaran ship hull which according to Bustos et al., [7] have an additional component besides frictional and residual resistance component, such as interference effects between the hulls. Therefore, model testing and numerical simulations were investigated.

\section{Methodology}

\subsection{Experimental Setup}

A Catamaran float model with symmetrical hull was configured in this investigation, where each hull having a step with slight amount of trim angle on its afterbody. The model is scaled into 1:10 dimension as depicted in Figure 1. The geometric characteristic of the float model also shown in Table 1.

Table 1

Main dimension of the floats model

\begin{tabular}{llll}
\hline Parameter & Symbol & Main Hull & Demi Hull \\
\hline Length $(\mathrm{m})$ & LoA & 1.23 & 1.23 \\
Beam $(\mathrm{m})$ & $B$ & 0.13 & 0.13 \\
Draft $(\mathrm{m})$ & $T$ & 0.042 & 0.042 \\
Block coefficient & $C b$ & 0.35 & 0.35 \\
Waterplane-area coefficient & $C w$ & 0.0016 & 0.0016 \\
Prismatic coefficient & $C p$ & 0.45 & 0.45 \\
Displacement $(\mathrm{kg})$ & $\mathrm{C}$ & 2.6 & 2.6 \\
Wetted surface area $\left(\mathrm{m}^{2}\right)$ & $\mathrm{Sa}$ & 0.00321 & 0.00321 \\
\hline
\end{tabular}

Three variations of hull separations are tested within Froude number ranged from 0.4 to 0.75 , the experiment was held in calm water condition with a towing tank that has $50 \mathrm{~m}$ long, $25 \mathrm{~m}$ wide, and $2 \mathrm{~m}$ depth following the ITTC Procedure [8]. The experimental setup consisted of a load cell device attached to the model to measure the total resistance of the model. The load cell than transmit the data into a processing software via Bluetooth. Therefore, various data including time, Froude number, and total resistance were obtained. In order to achieve accurate data, each test was held 3 times. A $2 \mathrm{~kg}$ of ballast were placed in the model, simulating the Operating Empty Weight (OEW) of the IAe's N219 Nurtanio Aircraft.

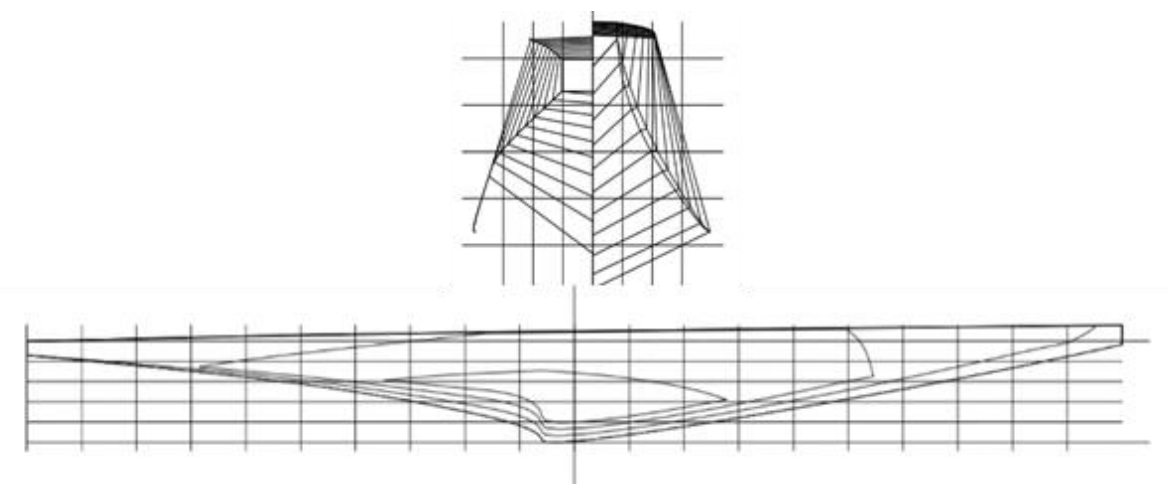

Fig. 1. Lines plan of the floats model 
The separation variations configuration ranged between $S / L 0.15$ to 0.25 , the separation was determined based on data that has been applied to aircraft with similar weight and size, the separation variations configuration can be seen on Table 2 and Figure 2.

Table 2

Hull Separations of The Floats

\begin{tabular}{lll}
\hline Configuration & S/L Ratio & Distance $(\mathrm{m})$ \\
\hline A & 0.15 & 0.19 \\
B & 0.20 & 0.255 \\
C & 0.25 & 0.315 \\
\hline
\end{tabular}

A

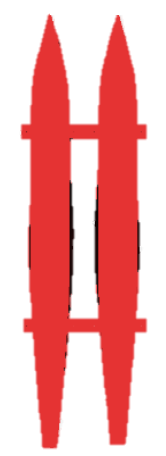

B

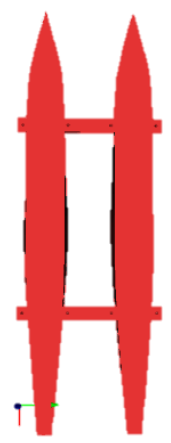

C

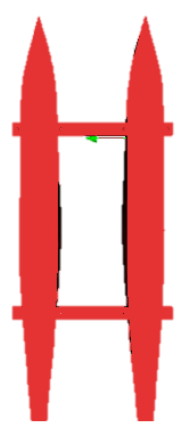

Fig. 2. Configuration of The Floats

Yanuar and Ibadurrahman [9] stated that both wave resistance and viscous resistance affect the ship total resistance, with viscous resistance being dominated by frictional influenced by the form factor of the hull on the low-speed range, especially on floats with step configuration. The step allows the hull to significantly reduce the wetted surface area when it reached planning condition, therefore the total water resistance gradually decreased along with increasing speed of the hull as stated by Canamar Leyva [4]. Otherwise, on high-speed range the wave resistance has more influence on the total resistance calculation. The total resistance coefficient calculated with the formula below:

$C_{T}=\frac{R_{T}}{0.5 \rho v_{S}^{2} S}$

The effects of viscous and wave interference occur due to interference between the two catamaran hulls, calculations and experiments are carried out to investigate the interference phenomenon on twin hull floats, according to Zaghi et al., [10] the interference factor can be determined by comparing the resistance components of the multihull with single hull of the multihull combined. The interference factor can be formulated with equations below

$I F=\frac{C_{T}^{(C)}-C_{T}^{(M)}}{C_{T}^{(M)}}$

with $C_{T}{ }^{(C)}$ as a total resistance coefficient from a catamaran and $C_{T}{ }^{(M)}$ as a total resistance from a single hull of the catamaran. Interference value is affected by hull separations variations and better when its value was lower according to Souto-Iglesias et al., [11]. 


\subsection{Numerical Setup}

Domains was built as a box around the hull as shown in Figure 3 with the boundary standard recommended by ITTC [12] with the Inlet being 1-L in front of the model ship with input in the form of fixed velocity in the form of the speed of the ship, outflow is 2-L behind the model ship with constant pressure. With boundary being 1-L of the ship and symmetry being half the length of the separations between the hulls. $L$ is the $L w l$ of the float model as figured in Figure 4 . A refinement box was made around the hull's draft with refinement value of 2 to make sure the smoothness of the mesh around the volume of air and water will be bordered. Demi-hull is placed at half of hull separations from the symmetry plane. A mesh convergence was set with 743302 number of cells with grid analysis resulting $7.6 \%$ of errors. As free surface simulations to be conducted, volume of fluid (VOF) was method was used, VOF method is based on the volume fraction of the fluid $(\alpha)$ as stated by Farkas et al., [13].
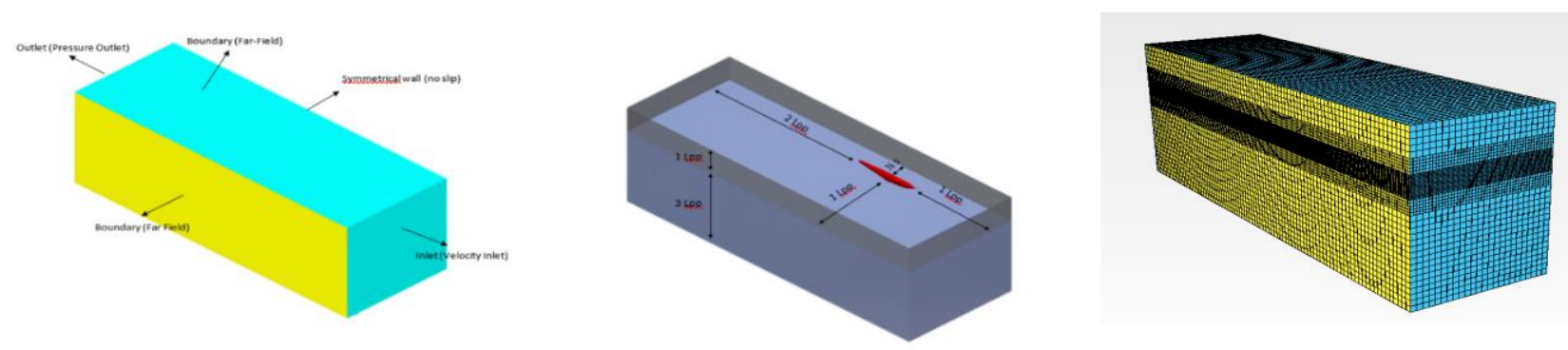

Fig. 3. Applied boundary conditions, mesh condition and size domain of the simulations

A RANS (Reynold Average Navier-Stokes) is modelled in this simulation and a transport property are needed for linear eddy viscosity models to represent the turbulence properties of the flows. The turbulence k-Omega Shear Stress Transport (SST) model is chosen to represent the turbulence properties. The k-Omega SST method, according to Bustos et al., [7] has a two-equation linear eddyviscosity model $A$ steady state with three-dimensional flow was implemented in numerical process with constant air and sea water properties. A series of time steps can be determined in steady state solutions to adjust the mesh convergence in steady state. It allows fixed time step size to be used in the entire domain stream, as stated by Seo et al., [14], time steps can be formulated with governing equation below

$\Delta \mathrm{t}=\frac{L}{2 U}$

The numerical process was solved with 5 seconds time control, with time steps $(\Delta t)$ value of 0.0001 and 0.1 second of run time. The process was run using numerical applicable equations, with form of mass, momentum, total pressure, and flow velocity as its components. Results is visualized in the post-processing software. Validation was done by comparing the value of total resistance coefficient and interference effect of the floats with such results from the experimental investigation held before.

\section{Results}

CFDSOF calculate the total resistance component forces of pressure, routine, viscous forces in and around the model, as stated by Song et al., [15]. Figure 4 and Figure 5 shows the wave pattern of the floats in low and high Froude numbers. Froude number and hull separations of the twin-hull 
configurated the same as the experimental investigated before. Figure 6 shows the total resistance and the total coefficient resistance and Figure 7 shows the interference factor of the experiment and numerical data compared as a validation process.

Total resistance coefficient on the $y$ axis compared with the range of Froude number on the $x$ axis. We can see the total resistance coefficient which numerically as with the experimental investigation the trend also shows that the hull with least value of the hull variations separations (S/L $=0.15$ ) had the highest resistance coefficient trendline. In contrast, the hull variation separations with the highest value $(S / L=0.25)$ had the lowest resistance coefficient trendline. An interference factor numerical analysis was also held on this investigation, which according to Yanuar et al., [9] and Zaghi et al., [10] it has effects on drag reduction where the negative value of interference factor could lead to resistance decrease. In contrast, the positive value could lead to a resistance increase.

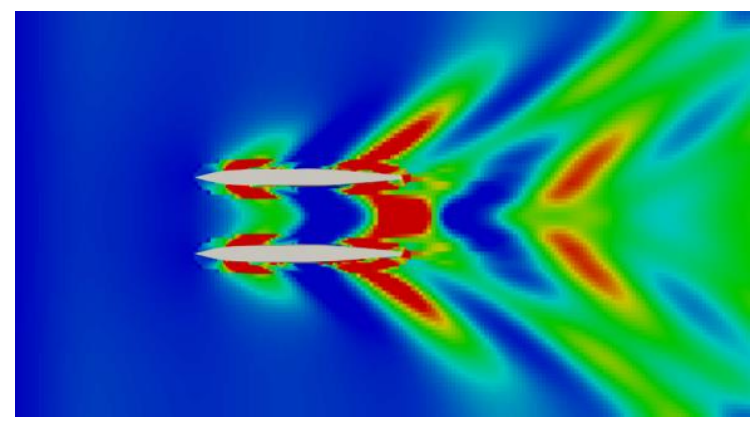

Fig. 4. Wave Pattern of the floats at $\mathrm{Fn}=0.4$

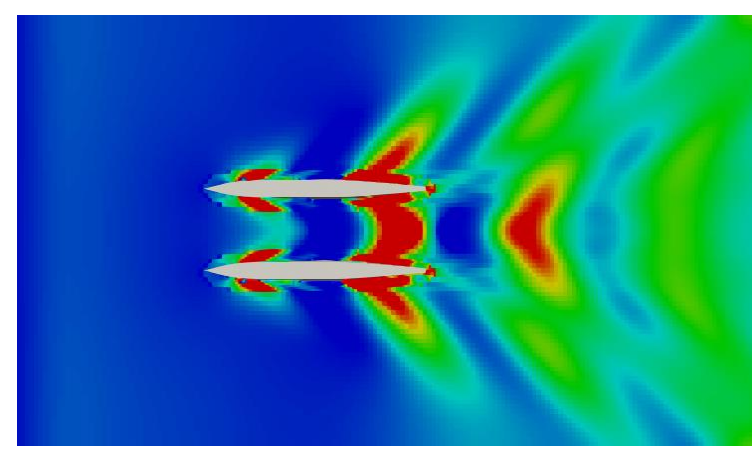

Fig. 5. Wave Pattern of the floats at $\mathrm{Fn}=0.5$
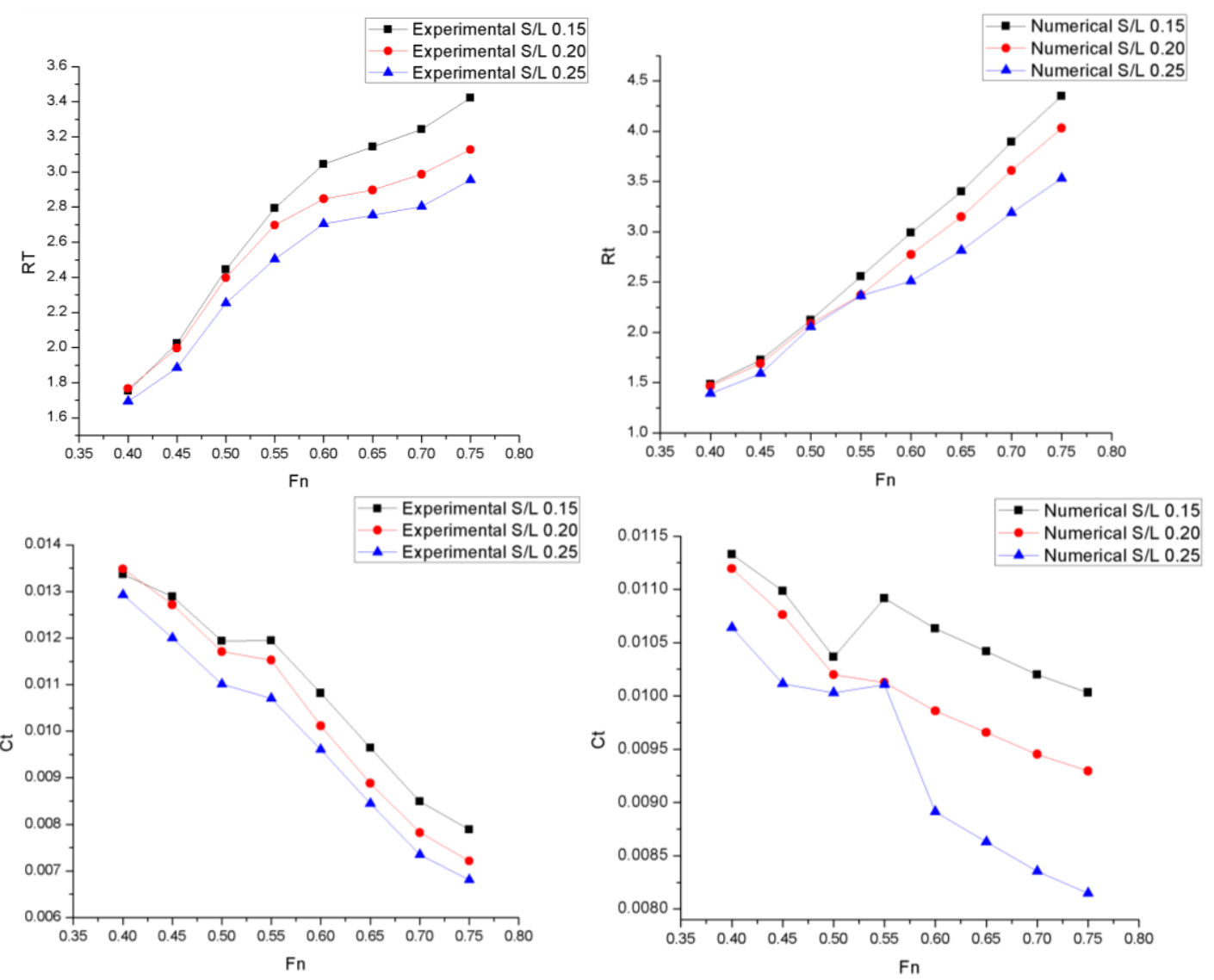

Fig. 6. The total resistance and total resistance coefficient of the model between experiment and numerical 

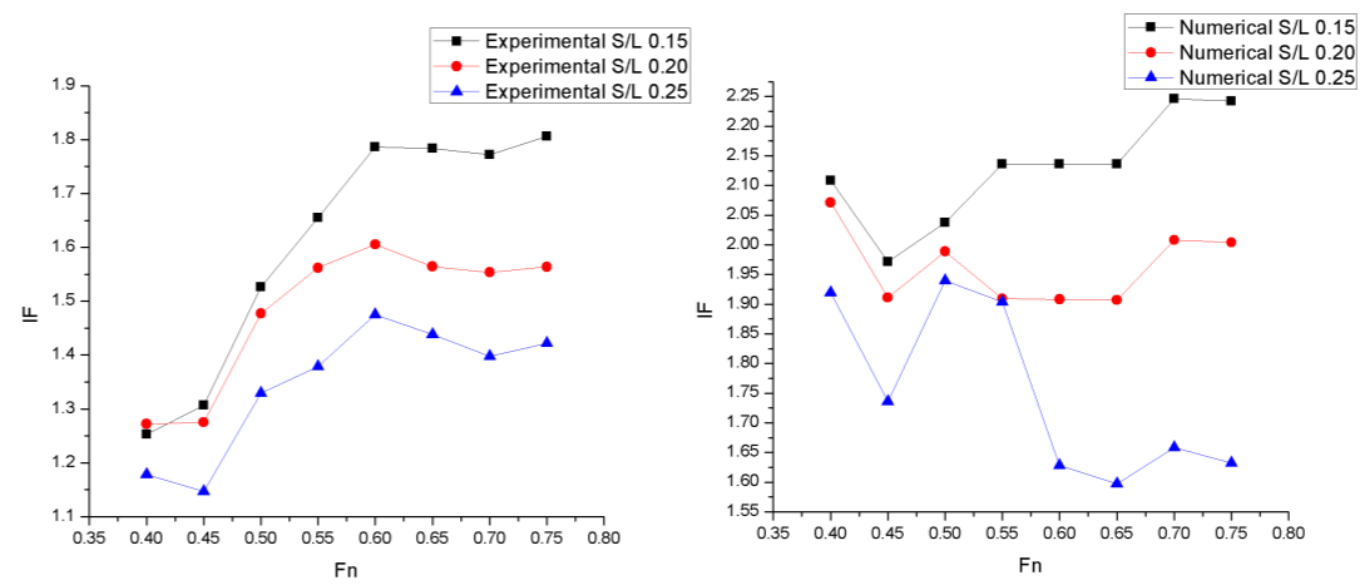

Fig. 7. The interference factor of the model between experiment and numerical compared

The interference factor is a factor that significantly influences the total resistance of the ship. The process happens because the two waves come together from the motion of the two hulls. It occurs in ships that have two or more hulls, including the catamaran floating pontoon which has a twin float configuration with two hulls like a catamaran. The interference factor can be negative or positive. If it is negative, then the interference that occurs is beneficial destructive interference, because the amplitude between the waves weakens each other so that the total resistance blocked by the resistance decreases. If it is positive, there will be constructive interference which results in the two waves having an amplitude between the waves which reinforces each other and increases the wave resistance which will affect the increase in total resistance.

When viewed on the graph, the trend line with the lowest interference factor value is shown by the variation in the configuration with a clearance distance $(S / L=0.25)$ at the Froude number 0.45 . It can be seen that the greater the clearance distance, the smaller the value of the resulting interference factor. So, it can be concluded that the clearance distance affects the total resistance value, with the clearance distance with the most significant value having the smallest total resistance. However, the value of the smallest interference factor is still positive with a value of 1.14684 at the clearance distance $(S / L=0.25$ ) with a Froude number of 0.45 . This indicates that the variation with the most outstanding value $(S / L)$ still has constructive interference which is not favourable for ship resistance. However, suppose it is seen from the experimental data. In that case, there is a possibility of destructive interference which is beneficial to ship resistance if the value of the variation in the clearance configuration is enlarged.

In numerical experiments, the interference factor tends to have a trend with lower interference factor values when compared to experimental data. This happens because the sinkage and trim factors are not taken into account in the numerical test. However, looking at the graph, the value with the lowest interference factor is still on the same Froude number and clearance configuration, namely the Froude number 0.45 and clearance $(S / L=0.25)$. The highest error number, when compared with the experimental results, is $19.58 \%$ in the clearance distance configuration (S / L 0.15) on Froude number 0.40 of 1.78644 and the smallest error is $10.41 \%$ on the clearance (S / L 0.20) on Froude number 0.60 with a value of 1.60651 . 


\section{Conclusions}

Based on the discussion that has been carried out from the discussion section, the following conclusions can be made

i. The Interference Factor (IF) with the smallest value occurs in configuration variations with a clearance distance (S / L) of 0.25 on Froude Number 0.45 with a value of 1.14684 in experimental testing and 1.73604 in numerical testing

ii. The value of the Interference Factor (IF) shows a positive result (+) in all variations of the configuration, indicating that there is no drag reduction at the variation of clearance distances (S/L) $0.15,0.20$, and 0.25 . However, drag reduction can occur at a more significant variation in clearance distances.

iii. 3. The results show that the clearance level of 0.25 is a better configuration than several clearance levels so that a reduced resistance produced by the configuration.

\section{Acknowledgement}

The work is sponsored by Hibah Kemenristek/BRIN TA 2020 ADD-NKB2669/UN2.RST/HKP.05.00/2020.

\section{References}

[1] Meekins, John A., and William Husa. “Amphibious Aircraft - U.S. Patent 8,272,596." Leader Industries, Inc., September 25, 2012. https://patents.justia.com/patent/8272596

[2] Liem, Rhea P. "Review of design aspects and challenges of efficient and quiet amphibious aircraft." In Journal of Physics: Conference Series, vol. 1005, no. 1, p. 012027. IOP Publishing, 2018. https://doi.org/10.1088/1742$\underline{6596 / 1005 / 1 / 012027}$

[3] Tetlow, M. R., and A. Smith. "Flight trials and drag analysis of a scale model floatplane." In 2007 IEEE Aerospace Conference, pp. 1-11. IEEE, 2007. https://doi.org/10.1109/AERO.2007.352735

[4] Canamar Leyva, Alan Leonel. "Seaplane conceptual design and sizing." PhD diss., University of Glasgow, 2012. https://doi.org/10.4271/2011-01-2696

[5] Broglia, Riccardo, Boris Jacob, Stefano Zaghi, Frederick Stern, and Angelo Olivieri. "Experimental investigation of interference effects for high-speed catamarans." Ocean Engineering 76 (2014): 75-85. https://doi.org/10.1016/i.oceaneng.2013.12.003

[6] Ibadurrahman, Ibadurrahman, A. Gunawan, and R. A. Wibowo. "Drag reduction of X-pentamaran ship model with asymmetric-hull outrigger configurations and hull separation." Energy Reports 6 (2020): 784-789. https://doi.org/10.1016/i.egyr.2019.11.158

[7] Bustos, Diana S. Hurtado, and Rubén J. Paredes Alvarado. "Numerical hull resistance calculation of a catamarán using OpenFOAM." Ship Science and Technology 11, no. 21 (2017): 29-39. https://doi.org/10.25043/19098642.150

[8] International Towing Tank Conference. "Recommended Procedures and Guidelines 7.5-02-02-01. Testing and Extrapolation Methods. Resistance Test." Specialist Committee: Procedures for Resistance, Propulsion and Propeller Open Water Tests of 23rd ITTC 2002 (2002): 1-11.

[9] Yanuar, and Ibadurrahman. "An investigation of the pentamaran resistance characteristic with variance in hull $\begin{array}{lllll}\text { combination and configuration." } & 156 & \text { (2019):469-474. }\end{array}$ https://doi.org/10.1016/i.egypro.2018.11.080

[10] Zaghi, Stefano, Riccardo Broglia, and Andrea Di Mascio. "Analysis of the interference effects for high-speed catamarans by model tests and numerical simulations." Ocean Engineering 38, no. 17-18 (2011): $2110-2122$. https://doi.org/10.1016/i.oceaneng.2011.09.037

[11] Souto-Iglesias, Antonio, David Fernández-Gutiérrez, and Luis Pérez-Rojas. "Experimental assessment of interference resistance for a Series 60 catamaran in free and fixed trim-sinkage conditions." Ocean Engineering 53 (2012): 38-47. https://doi.org/10.1016/j.oceaneng.2012.06.008

[12] International Towing Tank Conference. "ITTC - Recommended Procedures and Guidelines 7.5-03-02-03. Practical Guidelines for Ship CFD Applications." 26th ITTC Specialist Committee on CFD in Marine Hydrodynamics (2011): 118. 
[13] Farkas, Andrea, Nastia Degiuli, and Ivana Martić. "Numerical investigation into the interaction of resistance components for a series 60 catamaran." Ocean Engineering $146 \quad$ (2017): $151-169$. https://doi.org/10.1016/j.oceaneng.2017.09.043

[14] Seo, Jeong Hwa, Dong Myung Seol, Ju Hyun Lee, and Shin Hyung Rhee. "Flexible CFD meshing strategy for prediction of ship resistance and propulsion performance." International Journal of Naval Architecture and Ocean Engineering 2, no. 3 (2010): 139-145. https://doi.org/10.2478/IJNAOE-2013-0030

[15] Song, Soonseok, Yigit Kemal Demirel, Mehmet Atlar, Saishuai Dai, Sandy Day, and Osman Turan. "Validation of the CFD approach for modelling roughness effect on ship resistance." Ocean Engineering 200 (2020): 107029. https://doi.org/10.1016/i.oceaneng.2020.107029 